A COLONIAL AFFAIR 



\section{A COLONIAL AFFAIR}

COMMERCE, CONVERSION, AND SCANDAL IN FRENCH INDIA

Danna Agmon 
Publication of this open monograph was the result of Virginia Tech's participation in TOME (Toward an Open Monograph Ecosystem), a collaboration of the Association of American Universities, the Association of University Presses, and the Association of Research Libraries. TOME aims to expand the reach of long-form humanities and social science scholarship, including digital scholarship. Additionally, the program looks to ensure the sustainability of university press monograph publishing by supporting the highest quality scholarship and promoting a new ecology of scholarly publishing in which authors' institutions bear the costs of publication.

Funding from Virginia Tech made it possible to open this publication to the world.

\section{Copyright (C) 2017 by Cornell University}

All rights reserved. Except for brief quotations in a review, this book, or parts thereof, must not be reproduced in any form without permission in writing from the publisher. For information, address Cornell University Press, Sage House, 512 East State Street, Ithaca, New York 14850, or visit our website at www.cornellpress.cornell.edu.

First published 2017 by Cornell University Press

Printed in the United States of America

Library of Congress Cataloging-in-Publication Data

Names: Agmon, Danna, 1977- author.

Title: A colonial affair : commerce, conversion, and scandal in French India / Danna Agmon.

Description: Ithaca : Cornell University Press, 2017. Includes bibliographical references and index.

Identifiers: LCCN 2017008830 (print) | LCCN 2017010561 (ebook) | ISBN 9781501713064 (epub/mobi) | ISBN 9781501713071 (pdf) | ISBN 9781501709937 (cloth : alk. paper)

Subjects: LCSH: Puducherry (India : Union Territory) History—18th century. | French-India-Puducherry (Union Territory)—History—18th century. | Compagnie des Indes orientales-History.

Classification: LCC DS485.P66 (ebook) | LCC DS485.P66 A34 2017 (print) | DDC 954/.86029-dc23

LC record available at https://lccn.loc.gov/2017008830

The text of this book is licensed under a Creative Commons Attribution-NonCommercial-NoDerivatives 4.0 International License (CC BY-NC-ND 4.0): https: / / creativecommons.org/licenses/by-nc-nd/4.0/.

Cover illustration: Vüe de Pondichery dans les Indes Orientales, by Jacques-Gabriel Huquier (1730-1805) (Bibliothèque nationale de France) 
For Eli and Ido 
